\title{
Assessment of bird diversity as Bioindicators in two parks, Kolkata, India
}

\author{
Ranjini Chowdhury ${ }^{1}$, Subhodeep Sarkar ${ }^{1}$, Abantika Nandy ${ }^{2}$, \\ Soumendra Nath Talapatra ${ }^{2, *}$ \\ ${ }^{1}$ Department of Environmental Science, Asutosh College, \\ 92, S. P. Mukherjee Road, Kolkata - 700026, India \\ ${ }^{2}$ Department of Environmental Science, University of Calcutta, \\ 51/1 \& 2 Hazra Road, Kolkata - 700019, India \\ *Phone: 91-33-2461-5445 \\ *E-mail address: ecologylive@yahoo.co.in
}

\begin{abstract}
The trees of parks and gardens support many species, the survival of urban-dwelling species mainly bird species. Birds amongst other species provide a wide range of environmental and social functions to cities and urban dwellers. The present study aims to know bird diversity in two parks as bioindicator of automobile air pollution exposure, landscape changes and/or human interactions. The study areas were selected as per heavily-populated neighborhoods, nearby office buildings, nearby roads and continuous vehicular movements, human interactions as visitors, where high levels of human disturbance are common. The study was carried out at 2 sampling stations viz (i) Elliot park and (ii) Agri-horticulture Society. The bird species diversity was studied by qualitative and quantitative assessment. Indices were Species richness, Index of Dominance, Relative abundance, Shannon-Wiener Diversity Index and Evenness Index for birds for all selected sites were calculated using the statistical formulae. The present results as bioindicators bird species clearly indicate that the bird species are very few in numbers in both the parks. When comparison made between both the parks, it was observed less number of bird varieties (16 types) in Elliot park than varieties (9 types) more less in number in Agri-horticulture society. This study is a preliminary assessment of bird diversity but further researches are needed in relation to biochemical and genetic damage study as well as air pollution load by using instruments. In the present study it was concluded that the less numbers of birds and their different diversity indices were found a decreasing trends, though there no attempt has been made on physico-chemical properties of present air pollutants. The less number of varieties of bird species are as tolerant bioindicators, which may be due to the vehicular pollution and/or human interference and/or landscape changes due to nearby neighborhood blocks, office and residential buildings, continuous movement of vehicles etc.
\end{abstract}

Keywords: Bird diversity; Vehicular pollution; Urban park; Biomonitoring; Landscape change

\section{INTRODUCTION}

Greenspaces (parks and gardens) and forest trees contribute to a number of environmental functions in urban environments, such as the survival of urban-dwelling 
species mainly bird species. Birds amongst other species provide a wide range of environmental and social functions to cities and urban dwellers (Orians 1986; Costanza et al. 1997; Sanesi and Chiarello 2006; Padoa-Schioppa et al., 2007). Increasing levels of urban densification areas of great concern to those measures, which can mitigate urban land effects (Mazza and Rydin 1997) or compensate for the overload of pollutants in air and soil of urban area (McPherson et al., 1994; Nowak et al., 2006).

Birds are considered excellent bioindicators of the effects urbanization has on ecosystems since they are highly diverse and conspicuous biota of the ecosystem (PadoaSchioppa et al., 2006). Birds are also identified as indicators of aquatic and terrestrial habitat quality. Their ecology is well established and species respond easily to the availability of habitat structures (Clergeauetal et al., 1998; Tanveer et al., 2002; Evans et al., 2009). Also they respond rapidly to changes in landscape alteration, composition and function. Also birds are used as potent indicators of long-term environmental disturbances, such as air pollution, urbanization and landscape change. Thus, they are useful in-vivo test models for studying a variety of environmental problems (Newton, 1995; Navarro and Benítez, 1995; Blair, 1999; Hobson, 1999; Hobson and Rempel, 2001; Turner, 2002). Habitat loss due to landscape changes and/or human interference is the most important and often cited reason of loss of biodiversity (Palmer et al., 2004; Sidra et al., 2013).

There are many studies that have already been conducted on bird diversity in urban habitats viz. city parks, meadow remnants, community, private gardens etc. by many research works (Newton, 1995; Navarro and Benítez, 1995; Blair, 1999; Hobson and Rempel, 2001; Turner, 2002). However, few studies have been done in Indian context in urban habitats (Tanveer et al., 2002, Sidra et al., 2013). According to Tanveer et al. (2002), 64 species of birds at the New Campus of Punjab University have been studied. They have mentioned that habitat fragmentation, land use change and air and water pollution was some of the various factors that can affect the diversity of species in an area. Besides landscape change and/or human interference, air pollution by automobiles is a matter of great concern in India and as per CPCB, 2009; Citizen's Report, 2011, physico-chemical analysis of vehicular air pollutants revealed that still Kolkata is more susceptible to air pollution.

The present study aims to know bird diversity in two parks as bioindicator of environmental stresses. Actually no one has attempted in Kolkata to know bird as suitable bioindicator and can be identified by an easy screening of bird diversity near roadside of two parks.

\section{MATERIALS AND METHODS}

Kolkata with a population of 4.5 million as of 2011, the 3rd largest metropolitan area in India, centrally positioned at Latitude $=22^{\circ} 34^{\prime} \mathrm{N}$, Longitude $=88^{\circ} 21^{\prime} \mathrm{E}$ and covers an area of $1,026 \mathrm{~km}^{2}$. Situated at 5.18 meters above sea level. The study areas were selected as per heavily-populated neighborhoods, nearby office buildings, nearby roads and continuous vehicular movements, where high levels of human disturbance are common as visitors. The study was carried out at 2 sampling stations viz (i) Elliot park at Jwaharlal Nehuru road, (latitude $=22^{\circ} 32^{\prime} \mathrm{N}$ and longitude $=88^{\circ} 20^{\prime} \mathrm{E}$ ) and (ii) Agri-horticulture Society at Alipore Road (latitude $=22^{\circ} 31^{\prime} \mathrm{N}$ and longitude $=88^{\circ} 19^{\prime} \mathrm{E}$ ). The direct and indirect influences on bird species in two urban habitats, qualitative and quantitative assessment was done by 100 square meter line transects randomly within these two parks and evaluated relationships among variables for automobile pollution, green spaces and neighborhood/office blocks. 
Because our sampling design involved quantifying bird species in the field. Field survey was done by visual identification and image capture in this study. These two sampling stations mainly two parks were selected on the basis of human interference, moderate and heavy traffic density and continuous vehicular movement nearby roads as per visualization.

The diversity of visiting or inhabitant bird species were studied by qualitative and quantitative assessment as bioindicators. Field guides of Grimmett et al. (2001) and Mirza (2007) were used to identify the bird species (Tiwary, 2002). The highest number of each species observed was tabulated and statistical analysis was carried out using Microsoft Excel sheets. Relative Abundance of each bird species was calculated. Species richness, evenness, Shannon-Wiener Diversity Index, and Census Index for birds for all selected sites were calculated using the following statistics (Stiling, 1999):

$$
\text { Species Richness }(d)=S-1 / \ln N
$$

where, $\mathrm{S}=$ number of species, $\ln \mathrm{N}=$ natural logarithm of the total number of individuals

$$
\text { Index of Dominance }(\mathrm{C})=\sum(\mathrm{ni} / \mathrm{N})^{2}
$$

where, $\mathrm{ni}=$ importance value for each species (number of individuals), $\mathrm{N}=$ total number of importance value

\section{Relative abundance (Pi) $\mathrm{Pi}=\mathrm{Ni} / \mathrm{N}$}

where, $\mathrm{Ni}$ is the number of Individuals of a species, and $\mathrm{N}$ is total population of birds.

$$
\text { Shannon-Wiener diversity index (H') } \mathrm{H}^{\prime}=-\left[\sum \mathrm{Pi} \ln \mathrm{Pi}\right]
$$

where, $\mathrm{Pi}$ is proportion of species i relative to the total number of species, and $\ln P \mathrm{i}$ is natural logarithm of this proportion.

\section{Evenness index Species Evenness $=\mathrm{H}^{\prime} / \ln (\mathrm{S})$}

where, H' is Shannon Diversity Index; $\mathrm{S}$ is Species Richness (number of species), and $\ln (\mathrm{S})$ is natural logarithm of species Richness.

\section{RESULTS}

The present results of qualitative and quantitative study as bioindicators clearly indicate that the bird species are very few in numbers in both the parks (Table 1 and 2). When comparison made between both the parks, it was observed less number of bird varieties (16 types) in Elliot park than varieties (9 types) more less in number in Agri-horticulture society.

In Elliot Park, total number of individual bird species was observed 38 in 08:00 to 9:00 $\mathrm{AM}, 38$ in 10:00 to 11:00 AM and 31 in 12:00 to 1:00 PM while in Agri-Horticulture Society 18 in 08:00 to 9:00 AM, 13 in 10:00 to 11:00 and 15 in 12:00 to 1:00 PM were observed. The bird species varieties were observed pond heron (Ardeola grayii), swan (Cygnus atratus), duck (Cairina scutulata), little cormorant (Microcarbo niger), large cormorant (Phalacrocorax fuscicollis), common mayna (Acridotheres tristis), woodpecker (Melanerpes superciliaris), green parrot (Psiticula krameri), asian pied starling (Sturnus contra), house 
sparrow (Passer domesticus), kite (Milvus migrans), white browed wagtail (Motacilla maderuspatensis), black drongo (Ducrurus macrocercus), red whiskered bulbul (Pycnonotus jocosus), house crow (Corvus splendens) and house pigeon (Columba livia) in Elliot Park while in Agri-Horticulture Society, common myna (Acridotheres tristis), cuckoo (Cuculus canorus), common dove (Columbigallina passerina), house pigeon (Columba livia), black headed oriole (Panthera pardus), house crow (Corvus splendens), kite (Milvus migrans), asian pied starling (Sturnus contra) and green parrot (Psiticula krameri) were observed. Aquatic birds were not observed during the study period in the pond of Agri-horticulture society (Table 1).

It was observed for different diversity indices for bird species in time-wise interval (Table 2), the species richness was found 10 at 8.00-9.00 AM, 10 at 10.00-11.00 AM and 7 at 12.00-1.00PM in Elliot park and at Agri-horticulture society 6 at 8.00-9.00 AM , 6 at 10.0011.00 AM 5 at 12.00-1.00 PM. For index of dominance value is 0.14 (8.00-9.00 AM), 0.22 (10:00-11:00 AM), 0.20 (12:00-1:00 PM), at Elliot park and 0.26 (8:00-9:00 AM), 0.21 (10:00-1100 AM), 0.47 (12:00-1:00 PM) at Agri-horticulture society. In case of relative abundance 1.00 (8:00-9:00 AM), 1.00 (10:00-11:00 AM), 1.00 (12:00-1:00 PM) at Elliot park and 1.00 (8:00-9:00 AM), 1.00 (10:00-11:00 AM), 1.00 (1200-1:00 PM) at Agri-horticulture society. For Shanon-Weiner diversity index was observed 2.11 (8:00-9:00 AM), 1.89 (10:0011:00 AM), 1.71 (12:00-1:00 PM) at Elliot park while 1.55 (8:00-9:00 AM), 1.67 (10:0011:00 AM), 1.08 (12:00-1:00 PM) at Agri- horticultural society. In case of evenness index, it was observed 0.91 (8:00-9:00 AM), 0.82 (10:00-11:00 AM), 0.88 (12:00-1:00 PM) at Elliot park and 0.82 (8:00-9:00 AM), 0.93 (10:00-11:00 AM), 0.67 (12:00-1:00 PM) at Agrihorticulture society. In case of census index, it was observed 0.38 (8-9am), 0.38 (10-11am), $0.31(12-1 \mathrm{pm})$ at Elliot park while $0.18(8-9 \mathrm{am}), 0.13(10-11 \mathrm{am}), 0.15(12-1 \mathrm{pm})$ at Agrihorticulture society.

Table 1. Assessment of bird diversity in Elliot Park and Agri-Horticulture Society, Kolkata.

\begin{tabular}{|c|c|c|c|c|c|c|}
\hline \multirow[b]{2}{*}{ SI no. } & \multicolumn{3}{|c|}{ ELLIOT PARK } & \multicolumn{3}{|c|}{ AGRI-HORTICULTURESOCIETY } \\
\hline & $\begin{array}{c}\text { Bird species } \\
\text { (common name) }\end{array}$ & $\begin{array}{c}\text { Bird species. } \\
\text { (scientific name) }\end{array}$ & $\begin{array}{c}\text { No. of } \\
\text { individual } \\
\text { species }\end{array}$ & $\begin{array}{c}\text { Bird species. } \\
\text { (common name) }\end{array}$ & $\begin{array}{c}\text { Bird species. } \\
\text { (scientific name) }\end{array}$ & $\begin{array}{c}\text { No. of } \\
\text { individual } \\
\text { species }\end{array}$ \\
\hline 1. & Pond heron & Ardeola grayii & $\mathrm{P}=0 \mathrm{col}$ & Common mayna & $\begin{array}{c}\text { Acridotheres } \\
\text { tristis }\end{array}$ & $\mathrm{P}_{\mathrm{P}}$ \\
\hline 2. & Swan & Cygnus atratus & 2 & Cuckoo & Cuculus canorus & 3 \\
\hline 3. & Duck & Cairina scutulata & 7 & Common dove & $\begin{array}{c}\text { Columbigallina } \\
\text { passerine }\end{array}$ & 7 \\
\hline 4. & Large cormorant & $\begin{array}{c}\text { Phalacrocorax } \\
\text { fuscicollis }\end{array}$ & 4 & House Pigeon & Columba livia & 1 \\
\hline 5. & Little cormorant & Microcarbo niger & 3 & $\begin{array}{l}\text { Black Headed } \\
\text { Oriole }\end{array}$ & Panthera pardus & 1 \\
\hline 6. & Common mayna & Acridotheres tristis & 8 & House Crow & Corvus splendens & 22 \\
\hline 7. & Woodpecker & $\begin{array}{l}\text { Melanerpes } \\
\text { superciliaris }\end{array}$ & 1 & Kite & Milvus migrans & 2 \\
\hline 8. & Green parrot & Psiticula krameri & 1 & $\begin{array}{l}\text { Asian pied } \\
\text { starling }\end{array}$ & Sturnus contra & 2 \\
\hline 9. & $\begin{array}{l}\text { Asian pied } \\
\text { starling }\end{array}$ & Sturnus contra & 18 & Green parrot & Psittacula krameri & 4 \\
\hline
\end{tabular}




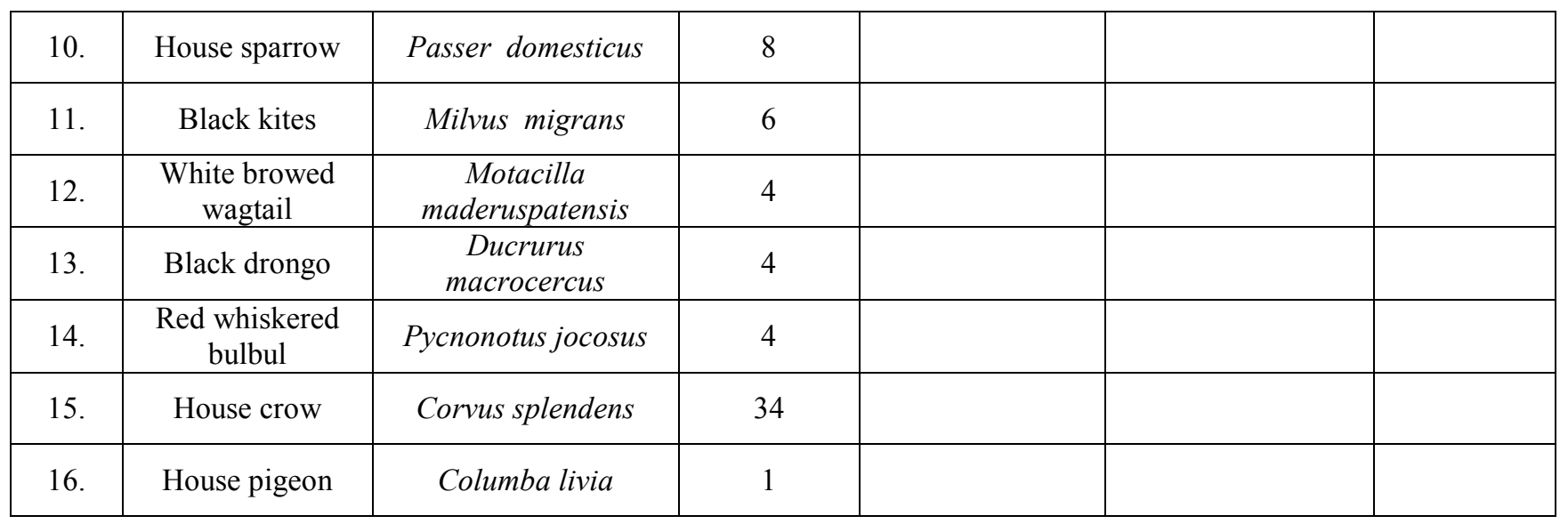

Table 2. Comparison of different indices for bird diversity between Elliot park and Agri-Horticulture Society, Kolkata.

\begin{tabular}{|c|c|c|c|c|c|c|c|}
\hline \multirow{2}{*}{$\begin{array}{c}\text { Sl. } \\
\text { No. }\end{array}$} & \multirow{2}{*}{ Different indices } & \multicolumn{3}{|c|}{ Elliot park } & \multicolumn{3}{c|}{ Agri-Horticulture Society } \\
\cline { 3 - 8 } & $\begin{array}{c}8: 00-9: 00 \\
\text { AM }\end{array}$ & $\begin{array}{c}10: 00-11: 00 \\
\text { AM }\end{array}$ & $\begin{array}{c}12: 00-1.00 \\
\text { PM }\end{array}$ & $\begin{array}{c}8: 00-9: 00 \\
\text { AM }\end{array}$ & $\begin{array}{c}10: 00-11: 00 \\
\text { AM }\end{array}$ & $\begin{array}{c}12: 00-1.00 \\
\text { PM }\end{array}$ \\
\hline 1. & Species richness & 10 & 10 & 7 & 6 & 6 & 5 \\
\hline 2. & Index of dominance & 0.14 & 0.22 & 0.20 & 0.26 & 0.21 & 0.47 \\
\hline 3. & Relative abundance & 1.00 & 1.00 & 1.00 & 1.00 & 1.00 & 1.00 \\
\hline 4. & $\begin{array}{c}\text { Shanon-Weiner } \\
\text { Diversity index }\end{array}$ & 2.11 & 1.89 & 1.71 & 1.55 & 1.67 & 1.08 \\
\hline 5. & Evenness index & 0.91 & 0.82 & 0.88 & 0.82 & 0.93 & 0.67 \\
\hline 6. & Census index & 0.38 & 0.38 & 0.31 & 0.18 & 0.13 & 0.15 \\
\hline
\end{tabular}

\section{DISCUSSION AND CONCLUSION}

The present study of bird diversity in two parks of Kolkata namely Elliot park and Agri- horticulture society indicates that the bird species by varieties are very few in numbers in both the parks (Table 1), since birds are highly diverse and conspicuous species of the ecosystem and birds as sentinel to environmental stresses (Newton, 1995; Navarro and Benítez, 1995; Blair, 1999; Hobson and Rempel, 2001; Turner, 2002).

It was established that the green spaces' (cemeteries, parks, gardens etc.) provide an important research area within the city because the dimension of the green space and the amount of tree cover are critical factors supporting avian ecological diversity in urban environments. The study of bird diversity besides office, residential buildings, large parks and reserves in urban areas where humans interact with the nature on a daily basis may support high species diversity because these protected areas are the habitat fragments of 
highly diverse ecosystems (Schaefer 1994) .Increasing urbanization adjacent to natural areas and parks often results in a community of birds with fewer species dominated by abundant non-native species (Marzluff et al., 1998).

Generally urban air pollution is a matter of great concern (Li, 2003). Pollution can reduce the survival of both adult birds and nestlings. This decrease may also be species and sex-specific, females being more vulnerable to pollutants than males. The lower survival rates of birds in polluted areas may also be due to higher emigration from the low quality and unproductive habitat rather than to the direct mortality of adult birds for instance from heavy metal poisoning (Belskii et al., 1995; Eeva and Lehikoinen, 1998; Eeva et al., 2008; Eeva et al., 2009) for dispersal distances. Heavy metal pollution loads in birds may differ between different tissues and organs and in different age stages (juveniles vs. adults) or between females and males (Hutton and Goodman 1980; Janiga and Žemberyová 1998; Swaileh and Sansur 2006). Pollution may cause environmentally mediated stress effects in nestling and adult birds either directly or indirectly, via reduced food availability that affects a bird's condition and phenotype, such as carotenoid based plumage coloration (Eeva et al. 1998; Belskii et al. 2005; Eeva et al. 2005; Berglund et al. 2007; Isaksson et al., 2007; Dauwe and Eens, 2008; Geens et al., 2009). The adverse impacts of air pollution, human interference and/or landscape change on avian population have already been studied by many researchers nationally and internationally. The present study has evidence with other researches that lower the numbers of bird species, automobile air pollution may be causative factor at nearby park. The park in Agri-horticulture society may have more air pollutants by continuous movements of automobiles and sentinel for bird species due to less number of species were observed.

However the ongoing trend in the development of urban areas is in general not positive for biodiversity maintenance, mainly due to continued growth of roads and buildings to meet the demands from an increasing number of citizens (Niemela, 1999; Yokohari et al., 2000). During recent decades there has also been an urban sprawl in the sense that large parts of the landscape surrounding cities has become increasingly urbanized. The studies have already been done on physico-chemical analysis by air pollution in Kolkata (CPCB, 2009; Citizen's Report, 2011) but no one has attempted easy screening of bird diversity near roadside two parks as bioindicator by automobile pollutants exposure, landscape changes and/or human interactions.

Sparrows could be used to monitor air pollution. Sparrows are living in the more highly-polluted urban sites had significantly lower haemoglobin concentrations and reduced anti-oxidant capacities, which the researchers were established that urban sparrows are exposed to higher concentrations of toxic chemicals, very likely as a result of the greater air pollution in these areas. The researchers conclude that this method could be a useful measure of how air pollution affects animals. The present study was emphasized that the sparrow species were only observed few in Elliot park not in Agri-horticulture society, which indicates the second park may have more air pollutants load and sparrow species have migrated in other places (Dueñas et al., 2014).

Although there are a large number of trees in botanical gardens, and lawns of departments and along with the roads, they may not be a good alternative for many species. Throughout the day these places are occupied by people, students, visitors or residents of the colony. The noise of the traffic and people can also disturb many avian species (Sidra et al., 2013). This finding supports with evident for other researchers that both the parks are visited by local people and human interaction may have another causative factor for less species diversity of bird. It was also known from other researches that densely populated areas had 
low bird diversity for the United Kingdom, for cities in North America, Europe, and Japan, which supports the present findings that both the parks were located in the cities (Turner et al. 2004; Tratalos et al., 2007a; b). According to Hadidian et al. (1997), the bird species richness were also reported lowest of the total estimation in commercial areas within Washington DC.

In the present study it was concluded that the less numbers of birds and their different diversity indices were found a decreasing trends (Table 2), which may be the effects of individual and/or combination of air pollutants, human interference, landscape change etc, though there no attempt has been made on physico-chemical properties of present air pollutants. It was estimated by the other researchers that in Indian cities, the concentrations of phytotoxic air pollutants often exceed the toxic limits (Trivedi et al., 2003; CPCB, 2009). This study is a preliminary assessment of bird diversity that have already been studied in green space, garden etc. in other parts of globe for aesthetical view of human and biodiversity conservation but further researches are needed in relation to biochemical and genetic damage study in the available bird species as well as air pollution load by using instruments. It was observed that the present bird species are common and more tolerant species but less in number, which may be due to the vehicular air pollution and/or human interference and/or landscape changes due to neighborhood blocks, office and residential buildings etc.

\section{Acknowledgement}

The authors convey their gratitude to the Department of Environmental Science, University of Calcutta, for providing the necessary facilities for doing this study.

\section{References}

[1] Belskii E.A., Bezel V.S., Lyakhov A.G., Russ J Ecol 26 (1995) 126-131.

[2] Belskii E.A., Lugas'kova, N.V., Karfidova A.A., Russ J Ecol 36 (2005) 329-335.

[3] Berglund Å.M.M., Sturve J., Förlin L., Nyholm N.E.I., Environ Res 105 (2007) 330-339.

[4] Blair R.B., Ecol Appl 9 (1999) 164-170.

[5] Citizen's Report, Centre of Science and Environment (2011) 1-106.

[4] Clergeau P., Savard J.-P.L., Mennechez G., Falardeau G., Condor 100(3) (1998) 413-425.

[5] Costanza R., d'Arge R., de Groot S., Farber M., Grasso B., Hannon B., Limburg S., O’Neil N.R., Paruelo J., Raskin R.G., Sutton P., van den Belt M., Nature 387 (1997) 253-260.

[6] CPCB, Central Pollution Control Board, New Delhi, (2009). http://www.cpcb.nic. in/bulletin /del/2009html.

[7] Dauwe T., Eens M., Naturwissenschaften 95 (2008) 969-973.

[8] Dueñas A.H., Pineda J., Antonio M.T., Aguirre J.I., Ecological Indicators 42 (2014) 6-9.

[9] Eeva T., Ahola M., Laaksonen T., Lehikoinen E., Oecologia 157 (2008) 231-238.

[10] Eeva T., Ahola M., Lehikoinen E., Env Polln 157 (2009) 126-131.

[11] Eeva T., Hakkarainen H., Belskii E., Env Polln 157(2009) 1857-1861. 
[12] Eeva T. ,Lehikoinen E., Écoscience 5 (1998) 46-50.

[13] Eeva T., Lehikoinen E., Rönkä M., Functional Ecol 12 (1998) 607-612.

[14] Eeva T., Ryömä M., Riihimäki J., Oecologia 145 (2005) 629-639.

[15] Geens A., Dauwe T., Eens M., Comp Biochm Physiol 150 (2009) 155-163.

[16] Grimmett R., Roberts T., Inskipp T., Helm Field Guides. Yale University Press (2001).

[17] Hadidian J., Sauer J., Swarth C., Handly D., Droege S., Williams C., Huff J., Didden G., Urban Ecosystems 1(2) (1997) 87-102.

[18] Hobson, K.A., Oecologia 120 (1999) 314-326.

[19] Hobson K.A., Rempel R., The Saskat-chewan For Impacts Monitoring Scientific Advisory Board (2001).

[20] Hutton M., Goodman G.T., Environ Pollun Ser A 22 (1980) 207-217.

[21] Isaksson C., McLaughlin P., Monaghan P., Andersson S., Functional Ecol 21 (2007) 1123-1129.

[22] Isaksson C., Von Post M., Andersson S., Biol J Linnean Soc 92 (2007) 521-527.

[23] Janiga M., Žemberyová M., Arch Environ Contam Toxicol 35 (1998) 70-74.

[24] Li M. H., Arch Environ Contam Toxicol 45 (2003) 168-176.

[25] Mazza L., Rydin, Y., Prog Plann 47 (1997) 1-74.

[26] McPherson E.G., D.J. Nowak, Rowntree R.A., United States Department of Agriculture Forest Service Northeastern Forest Experiment Station General Technical Report NE1 (1994) 86.

[27] Melles S., Glenn S., Martin K., Conserv Ecol 7(1) (2003) 5.

[28] Marzluff J.M., Worldwide urbanization and its effects on birds. In: Avian ecology in an urbanizing world (eds. J. M. Marzluff, R. Bowman and R. Donnelly). Norwell, M. A. Kluwer Academic, (2001) pp. 19-47.

[29] Mirza Z.B., EDRC, WWF - P (2007).

[30] Navarro A., Benítez H., El dominio del aire, La Ciencia desde México, (138), Fondo de Cultura Económica, , A., Benitez, H, Mastering Air. 216. Science from Mexico, Fondo de Cultura Economica SEP- CONACYT 138 (1995).

[31] Newton I., J Anim Ecol 64 (1995) 675-696.

[32] Niemelä, J., Scandinavian Journal of Forest Research Supplementum 3 (2001) 70-78.

[33] Orians G.H., Lowenthal D., Meaning and values in landscape (1986).

[34] Palmer M. et al., Science 304 (2004) 1251-1252.

[35] Padoa-Schioppa, E. M. Baietto, R. Massa, L. Bottoni, Ecol Indicators 6 (2006) 83-93.

[36] Padoa-Schioppa, E. P. Digiovinazzo, L. Bottoni, In Bunce, R.G.H., Jongman, R.H.G., Hojas L., Weel, S., IALE World Congress 1 (2007) 274.

[37] Sandstrom U.G., Angelstama P., Mikusinski B.G., Landscape Urban Planning 77 (2006) 39-53. 
[38] Sanesi G., Chiarello F., Urban Forestry Urban Greening 4 (2006) 125-134.

[39] Savard J-P.L., Clergeaub P., Mennechezb G., Landscape and Urban Planning 48 (2000) 131-142.

[40] Sidra S., Ali Z., Chaudhry M.N., Pak J Zool 45(4) (2013) 1069-1082.

[41] Stiling P., Ecology: Theories and Applications ( $3^{\text {rd }}$ ed) (1999) Upper Saddle River, NJ: Prentice-Hall, Inc.

[42] Strohbach M.W, Haase, D., Kabisch, N., Ecology and Society 14 (2) (2009) 31.

[43] Tanveer A., Shahzad, M., Chaudhry, A.A., Pak J Zool 17 (2002) 35-51.

[44] Tiwary V.M., Joy of bird watching $1^{\text {st }}$ Ed (2002) 1-287.

[45] Tratalos J., Fuller R.A., Evans K.L., Davies R.G., Newson S.E., Greenwood J.J.D., Gaston K.J., Global Change Biol 13(8) (2007a) 1685-1695.

[46] Tratalos J., Fuller, R.A., Warren, P.H., Davies, R.G., Gaston, K.J., Landscape and Urban Planning 83(4) (2007b) 308-317.

[47] Trivedi S., Agrawal M., Rajput M., Indian J Air Poll Cont 3 (2003) 44-53.

[48] Turner W.R., Landscape Urban Plann 65 (2002) 149-166.

[49] Turner W. R., Nakamura T., Dinetti M., BioScience 54(6) (2004) 585-590.

[50] Yokohari M., Takeuchi K., Watanabe T., Yokota S., Landscape Urban Planning 47 (2000) 159-171. 